\title{
Progress of Molecular Floral Development Research in Wheat
}

\author{
Zaijun Yang \\ College of Life Science, China West Normal University \\ Nanchong, Sichuan, 637009, China \\ Key Laboratory of Crop Genetic Resources and Improvement Ministry of Education \\ Sichuan Agricultural University, Yaan, Sichuan, 625014, China \\ Zhengsong Peng (Corresponding author), Yan Yu \& Shuhong Wei \\ College of Life Science, China West Normal University \\ Nanchong, Sichuan, 637009, China \\ Tel: 86-817-256-8011Ｅ-mail:pzs8833@163.com
}

This work was supported by National Natural Science Foundation of China. No. 30871533

\begin{abstract}
Wheat (Triticum aestivum L.) is one of the most important crops in the world. Because the wheat floral organs provided the basis for grain formation, study of wheat floral development is important for improving wheat yield potential. In recent years, notable progress has been made in study of molecular floral development in wheat. In this review, we summarized the 'ABC' model and discussed the role of A-, B-, C-, D-, E-class genes in the development and evolution of wheat flowers and inflorescence.
\end{abstract}

Keywords: Wheat (Triticum aestivum L.), Floral development, MADS-box, ABC model

\section{Introduction}

Wheat (Triticum aestivum L.) is the most important food crop in the world and becomes even more important as the global population increases. Because the arable land is very limited, improving the yield is essential. One way to improve wheat yield potential is to increase grain number per spike (Coffman, 1924; Frederic and Bauer, 2000). The grain number of per spike is the ultimate embodiment of the floral differentiation, degeneration and grain-setting. Those physiological processes are closely related to the floral development in wheat. The inflorescence of a wheat plant (spike, ear or head), developed at the tip of the stem, is composed of spikelets. The spikelets are arranged to form two opposite rows along the main axis or rachis. The number of spikelets per spike is determined by the timing of terminal spikelet initiation, which depends on the genotype and the environmental conditions. In this respect, the rachis meristem in wheat is determinate. The spikelet is composed of florets joined at the axis (rachilla) alternately on opposite sides, and encompassed by two small bract leaves called glumes. There are multiple florets (usually six to eight) in each spikelet, of which a few in the apical positions may be sterile due to hypoplasia. In contrast to barley, rice and maize, the rachilla meristem in wheat is classified as indeterminate. A typical floret in wheat consists of four whorls. The first outermost whorl often consists of two leaf-like structures, a lemma and a palea. The lemma bears an awn at its tip in some cultivars, but there are also awnless cultivars such as Chinese Spring. It was recently suggested that the lemma and palea are homologous to dicot sepals in rice and maize (Ambrose et al., 2000; Kang et al., 1998). The second whorl is composed two lodicules. The lodicule is considered to be a modified petal in maize and rice (Ambrose et al., 2000; Kang et al., 1998; Kyozuka et al., 2000), which swells during anthesis, forcing the lemma and palea apart to facilitate pollination. The third whorl contains three stamens, that is, the male reproductive organs, which produce pollen. Finally, the fourth, innermost whorl contains a pistil, which has a unilocular carpel, is the female part of the flower and consists of the ovary containing the ovule and two filamentous styles, each terminating in a feathery stigma.

Although the structures and functions of lemma, palea, lodicule, stamens and carpels may differ dramatically at maturity, each floral organ starts its development as a little bulge on the floral meristem, a tiny clump of undifferentiated cells. Each cell in the developing floral organ primordium must somehow 'learn' its position within the floret, and differentiate accordingly into an appropriate cell type (Günter, 2001). 


\section{2. 'ABC model' and MADS-box gene}

Flower development has been the subject of intensive studies about twenty years ago, particularly in two dicot plants, Arabidopsis and Antirrhinum (Theissen and Saedler, 1999; Theissen, 2001). These studies have provided a general understanding of the development of floral organs in higher plants, explained by the ABC model (Davies and Schwarz-Sommer, 1994; Ma, 1994; Weigel and Meyerowitz, 1994). This model explains how floral organ identity is defined by three classes of homeotic genes, called A, B and C. In this model, each class functions in two adjacent floral whorls, class-A genes specify sepals in the first whorl; A and B, petals in the second whorl; B and C, stamens in the third whorl; and C, carpels in the fourth whorl. The ABC model continues to be revised since it is proposed. When FLORAL BINDING PROTEIN 11 (FBP11), termed D-class gene, is confirmed to determine ovule, ABCD model is suggested (Angenent and Colombo, 1996). Furthermore E-class gene and ABCDE model are proposed based on the fact that SEPALLATA1 (SEP1), SEPALLATA2 (SEP2), SEPALLATA3 (SEP3) are proven to be together with A-, B-, C-, D-class genes required for the specification of floral organ identities in Arabidopsis (Theissen, 2001). The 'classical ABCDE model', which has been widely accepted until now, was proposed to explain how homeotic genes control organ identity.

The all A-, B-, C-, D-, E-classes gene are homeotic genes, which are translated into proteins. Each protein coded by these genes contains a MADS-box region, which take their name from the MINICHROMOSOME MAINTENANCE 1 (MCMI) genes in yeast, AGAMOUS (AG) in Arabidopsis, DEFICENS (DEF) in Antirrhinum and SERUM RESPONSE FACTOR (SRF) in humans (Riechmann and Meyerowitz, 1997). All MADS-box genes have in common a highly conserved 180-bp-long motif designated MADS-box, which encodes the DNA-binding domain of MADS-domain proteins (Shore and Sharrocks, 1995; West et al., 1998; Alvarez-Buylla et al., 2000). It is believed that these genes are master controlling genes, regulating the action of other genes that will control organ development.

Analysis of the $\mathrm{ABCDE}$ genes in monocot species such as rice suggests that the $\mathrm{ABCDE}$ model could essentially be extended to monocots except for the role of the class A gene (Kater et al., 2006; Yamaguchi and Hirano, 2006). In wheat, it has reported some ABCDE genes, such as WAP1 (wheat AP1) (Murai et al., 1998; Murai et al., 2002), WAP3 (wheat APETALA3) (Murai et al., 1998), WPI1 (wheat PISTILLATA1) (Hama et al., 2004), WSEP (wheat SEPALLATA) (Shitsukawa et al., 2007), et al (Fig.1).

\section{AP1-like genes (A-class gene) in wheat}

In the core eudicot Arabidopsis, the A-class gene APETALA1 (AP1) is required for establishment of the floral meristem and for specification of sepal and petal identity (Mandel et al., 1992). Specification of floral meristem identity in Arabidopsis is redundantly regulated by the AP1 homologs CAULIFLOWER (CAL) and FRUITFUL (FUL) (Kempin et al., 1995, Ferrandiz et al., 2000). In rice, some APl-like genes, such as OsMADS14, OSMADS15, and OSMADS18 have been isolated and identified (Moon et al., 1999, Jeon et al., 2000, Kyozuka et al., 2000, Lim et al., 2000). The $A P$-like genes in rice suggest that they are playing a role in specifying floral meristem identity, but are not necessary in sepal and petal identity determination (Kater et al., 2006; Yamaguchi and Hirano, 2006).

The wheat genome contains at least six AP1-like MADS-box genes, WAP1, VRN1, TaVRT-1, TaAP1-1, TaAP1-2 and TaAP1-3 (Murai et al., 2003, Yan et al., 2003, Danyluk et al., 2003; Paolacci et al., 2007). WAP1 is 98.8\% identical to TaVRT-1 and has only three amino acid changes in C region. Otherwise, WAP1 is $98 \%$ identical to $V R N-1$ and has only five amino acid changes (Murai et al., 2003). WAP1 was isolated from spring wheat (T. aestivum) cv. Norin 26 (Murai et al., 1998, Murai et al., 2002), TaVRT-1 from winter wheat (T. aestivum) cv. Fredrick (Danyluk et al., 2003), and VRN-1 from T. monococcum (Yan et al., 2003). Those results suggesting that the three APl-like genes should represent the same gene and the difference of sequence is due to varietal polymorphism.

Phylogenetic study clearly indicated that the WAP1, VRN1, TaVRT-1, TaAP1-1, TaAP1-2 and TaAP1-3 are classified as relatively distant subclass of the monocot $A P 1$-like family (Murai et al., 2003; Paolacci et al., 2007). It will be interesting to determine whether these genes have functions similar to those of the AP1-like genes in endicots because the wheat floret does not have obvious sepals and petals, but instead has a lemma, a palea, and lodicules. But previous studies have suggested that WAPI, VRN1, TaVRT-1, TaAP1-1, TaAP1-2 and TaAP1-3 are only involved in the phase transition from vegetative to reproductive (Murai et al., 2003; Yan et al., 2003; Danyluk et al., 2003; Paolacci et al., 2007).

As an activator of phase transition, WAPl expression starts just before the phase transition and is maintained during the reproductive phase, and is up-regulated by vernalization and long photoperiod. The nulli-tetrasomic analysis indicated that WAP1 has three homoeologous genes located on chromosome 5A, 5B, and 5D 
respectively in allohexaploid wheat (Murai et al., 2003).

$V R N 1$ is ortholog of WAP1, and consequently three homoeologous genes of VRN1 located on group 5 homoeologous chromosomes (Yan et al., 2003). How is VRN1 gene up-regulated by vernalization? In diploid wheat, Dubcovsky et al. (1998) identified a second gene affecting vernalization response and named it VRN2. Contrary to the VRN1 dominant allele for spring growth habit, VRN2 allele for winter growth habit is dominant (Tranquilli and Dubcovsky, 2000). The effect of VRN1 on heading time was significant only when the dominant $V R N 2$ allele was present, that is VRN2 is epistatic to VRN1. Although the VRN2 gene has not been cloned, Yan et al. (2003) proposed a model of the vernalization pathway in diploid wheat according to the knowledge of the epistatic interactions between $V R N 1$ and $V R N 2$ and the available results. In their model, VRN2 encodes a repressor of VRN1 expression, which binds to the promoter region of the VRN1 gene. As the vernalization process reduces the abundance of the $V R N 2$ gene product, $V R N 1$ transcription gradually increased, leading to the competence to flower.

TaVRT-1 (Triticum aestivum vegetative to reproductive transition-1) which also identified as TaVRN1 (Kane et al.,2007) was isolated from winter wheat. Molecular and sequence analyses indicated that this gene encodes a protein homologous to the MADS-box family of transcription factors that comprises certain flowering control proteins in Arabidopsis. Mapping studies have localized this gene on the long arms regions of homeologous group 5 chromosomes. The level of expression of TaVRT-1 is positively associated with the vernalization response and transition from vegetative to reproductive phase (Danyluk et al., 2003).

TaAP1-1 is closely related to the wheat homoeologous genes TaVRN-1, (Fu et al., 2005), which are involved in the transition from vegetative to reproductive phase induced by vernalization. TaAP1-2 was expressed higher in mature leaves, spikes and in the flower vegetative organs, except the lodicules. TaAP1-3 was expressed in all development stages of spikes and in vegetative organs of the spikelets, but at lower level in the lodicules (Paolacci et al., 2007).

As a whole, the function of $A P 1$-like genes in wheat is still unclear, as compared to other species such as Arabidopsis and rice, probably owing to the lack of loss-of-function analysis and to the genetic redundancy of these genes.

\section{B-class genes in wheat}

As explained by the ABC model, class-B genes are involved in the homeotic transformation of stamens into carpel/pistil-like structures in dicots such as Arabidopsis (Goto and Meyerowitz, 1994; Jack et al., 1992) and Antirrhinum (Sommer et al., 1990; Tröbner et al., 1992). In monocots, transgenic rice expressing antisense RNA of the class-B gene OSMADS4 and OSMADS2 displayed alteration of stamens into a carpel-like organ (Kang et al., 1998), and a maize class-B gene-deficient mutant, silkyl, showed male sterility due to homeotic conversions of stamens into carpels (Ambrose et al., 2000). Nowadays, there are two AP3-like genes (TaMADS\#51 and TaMADS\#82) and four PI-like genes (WPI1, WPI2, TaPI-1 and TaPI-2) in wheat had been isolated and identified (Murai et al., 1998; Hama et al., 2004; Paolacci et al., 2007).

Murai et al. (1998) isolated two wheat AP3-type genes, TaMADS\#51 and TaMADS\#82, which are highly homologous to each other. Bread wheat is a hexaploid with genome constitution AABBDD and each genome originated from three diploid related species (Feldman, 2001). Therefore, the hexaploid wheat genome generally contains triplicated homeologous genes derived from the ancestral diploid species. TaMADS\#51 and TaMADS\#82 are homoeologous genes of the AP3 ortholog of wheat (WAP3), located on chromosomes 7B and $7 \mathrm{D}$, respectively. Northern blot analysis revealed that the expression of WAP3 was restricted to young spikes at the floral-organ-developing stage, suggesting that WAP3 functions in floral organ formation (Murai et al., 1998). At the same time, the WAP3 gene was reduced expression in the young spikes of the alloplasmic wheat line with pistillody compared with the normal line (Murai et al., 2002). This suggests the involvement of WAP3 in the induction of pistillody in the alloplasmic lines.

The wheat genome contains four PI-like genes, namely, WPI1, WPI2, TaPI-1 and TaPI-2. Phylogenetic reconstruction indicated that WPII is orthologous to OSMADS4 and that WPI2 is probably an ortholog of OsMADS2 (Murai et al., 2003). Both OsMADS4 and OsMADS2 genes were suggested to be PI orthologs in rice (Chung et al., 1995), and the function of OSMADS4 as a class-B gene was proven by the transgenic study (Kang et al., 1998). An in situ hybridization study demonstrated that the WPIl gene is expressed in primordia of lodicules and stamens in developing florets in wheat. In the alloplasmic wheat line exhibiting pistillody, the WPI1 transcripts were not detected in the primordia of pistil-like stamens, whereas WPII was expressed in the lodicules. (Murai et al., 2003). This clearly indicates that the pistillody resulted from a deficiency of WPII gene expression in whorl 3. Despite the homeotic change of stamens into pistil-like structures, normal lodicules are 
developed in the alloplasmic wheat line (Murai et al., 2002). The PI-like class-B gene WPII and WPI2 showed an expression pattern similar to that of WAP3 (TaMADS\#51 and TaMADS\#82). TaPI-1 and TaPI-2 are 99.5\% identical to WPI1 and WPI2, respectively, and there are only one amino acid changes. So TaPI-1 and WPI1, TaPI-2 and WPI2 may be representing the same gene. Those results revealed that down regulation of the class B genes wheat PISTILLATA (WPI) and wheat APETALA3 (WAP3) induces pistillody, the homeotic transformation of stamens into carpel-like organs (Hama et al., 2004).

\section{C-class genes in wheat}

C-class genes, such as Arabidopsis AGAMOUS $(A G)$ and rice OSMADS58 play important roles in the specification of stamen and carpel identity, the control of floral meristem determinacy, and the negative regulation of A-function gene activity (Coen et al., 1991). The wheat genome contains five C-class genes, WAGl, WAG2, TaMS-MADSbox, TaAG-1 and TaAG-2 (Meguro et al., 2003; Hirabayashi et al., 2009; Zhou et al., 2008; Paolacci et al., 2007). The same to the B-class genes in wheat, C-class genes could be associated with the induction of pistillody in the alloplasmic wheats.

Southern blot analysis proved that the wheat genome contains three homoeologous WAG-1 genes, located on the homoeologous chromosome group 1, 1A, 1B and 1D, and had two different WAG-1 gene transcripts (about 1.1 $\mathrm{kb}$ and $1.3 \mathrm{~kb}$ in size) in spikes at the booting to heading stage (Meguro et al., 2003). In the euplasmic and alloplasmic wheat lines, the $1.1 \mathrm{~kb} W A G-1$ gene transcript accumulates in both reproductive (pistil and stamen) and non-reproductive (palea and lemma) portions of spikes at the heading stage in both lines. However, the 1.3 $\mathrm{kb}$ transcript is restricted to pistil-like stamens of the line alloplasmic as well as to pistils of euplasmic line. These results suggest that the product of the $1.3 \mathrm{~kb}$ transcript is involved in pistil development, and is associated with the pistillody caused by the nuclear-cytoplasm interaction in alloplasmic wheat lines (Meguro et al., 2003).

Hirabayashi et al. (2009) identified a contig with high sequence similarity to OsMADS3 in rice (Kang et al., 1995) and ZMM2 in maize (Theissen et al., 1995), and named WAG-2. The phylogenetic tree indicated that the monocot class $\mathrm{C}$ gene family separated into two groups, $W A G-1$ clade and $W A G-2$ clade. The $W A G-1$ clade contains barley $H v A G 2$, rice $O S M A D S 58$ (Yamaguchi et al., 2006) and maize ZAG1 (Mena et al., 1996), whereas the WAG-2 clade insists of barley HvAG1, rice OSMADS3 (Kang et al., 1995) and maize ZMM2 (Theissen et al., 1995). This indicates that $A G$ orthologs were duplicated in each monocot species. The phylogenetic tree also indicates that dicot class C genes, Arabidopsis $A G$ and Antirrhinum PLE, are more close to $W A G-2$ clade than $W A G-1$ clade (Hirabayashi et al., 2009). But nowadays, the function about WAG-2 is unclear.

TaMS-MADSbox gene was isolated from thermo-sensitive male sterility line, and the results of RT-PCR showed that the expression of this gene in male sterile spikes was much higher than that in fertile spikes. It suggests that the expression of TaMS-MADSbox is related to the fertility conversion of male-sterile lines. The spikes are male-sterile under high-level expression of TaMS-MADSbox, while fertile under the low-level expression (Zhou et al., 2008).

RT-PCR detected the TaAG-1 and TaAG-2 with increasing levels during the spike development, in stamens and pistils. The only divergence was the ten times higher expression of TaAG-2 in stamens than in pistils, whereas the expression of TaAG-1 was similar in stamens and pistils (Paolacci et al., 2007).

In conclusion, the class $\mathrm{C}$ gene and class $\mathrm{B}$ gene have the similar functions in wheat, and they can induce pistillody. But there are still many gaps in our knowledge of pistillody in wheat. To understand the molecular mechanism of this phenomenon, we need to obtain other class $\mathrm{C}$ genes and class B genes that are expressed in stamen and pistil primordia.

\section{D-class genes in wheat}

Arabidopsis SEEDSTICK (STK) and its Petunia orthologs, FBP7 and FBP11, regulate ovule identity and these MADS-box genes are known as D-class genes (Colombo et al., 1995; Pinyopic et al., 2003). In Arabidopsis, the D-class gene $S T K$ and the C-class genes $A G, S H P 1$, and $S H P 2$ redundantly regulate the specification of ovule identity (Pinyopic et al., 2003). Until now, only three class D genes in wheat genomes had been isolated, namely, WSTK, TaAG-3 and TaAG-4 (Yamada et al., 2009; Paolacci et al., 2007). WSTK shows high similarity to OSMADS13, a class D gene in rice. The WSTK was isolated from pistil-like stamen in the alloplasmic wheat. The in situ expression analysis indicated that the WSTK was expressed in the primordia of ectopic ovule in the pistil-like stamens as well as in the true pistil, suggesting that the WSTK plays a role in determination of ovule identity in the pistil-like stamen, but complete ovule development fails due to aberrant expression of WBsis gene (Yamada et al., 2009). TaAG-3 and TaAG-4 had very divergent expression patterns. TaAG-4 showed a pattern similar to that of class $\mathrm{C}$ genes, but its expression was higher during late spike development, very weak in 
stamens, very high in pistils and caryopses; its expression pattern was compatible with its function as class D gene. TaAG-3 was expressed in glumes, palea, lemma, lodicules, stamens and pistil, suggesting a functional divergence from its orthologs in other species (Paolacci et al., 2007).

\section{SEP-LIKE GENES (E-class genes) in wheat}

Arabidopsis SEPALLATA genes (SEP1, SEP2, SEP3, and SEP4) form an integral part of the mechanisms underlying floral organ specification (Pelaz et al., 2000; Honma et al., 2001; Pelaz et al., 2001; Favaro et al., 2003; Ditta et al., 2004). These SEP-like genes can form heterochimeric protein complexes with the products of the class A, B, C and D genes that regulate identity acquirement of sepals, petals, stamens, carpels and ovules (Honma et al., 2001; Pelaz et al., 2001; Favaro et al., 2003). The SEP-like genes in the angiosperms are divided into two major clades: the SEP3 clade and the LOFSEP clade (Malcomber et al., 2005). The wheat genome contains nine SEP-like MADS-box genes: four of these, WSEP, TaMADS1, TaSEP-3 and TaSEP-4 are classified as members of the SEP3 clade, whereas the others, WLHS1, TaSEP-1, TaSEP-2, TaSEP-5 and TaSEP-6 are classified as member of the LOFSE (Shitsukawa et al., 2007; Xiang et al., 2006; Paolacci et al., 2007).

The TaMADS1 transcripts began to accumulate in spikelets, and then, in floret primordial and floral organ primordial in wheat. In the later stage of floret development, the TaMADS1 transcripts accumulated in four whorls of young floral organs. The ectopic expression of TaMADS1 in transgenic Arabidopsis caused early flowering and altered the development of all floral organs. Further studies demonstrated that the early flowering phenotype in transgenic plants could be correlated with the upregulation of some flowering time genes and flower meristem identity genes. The results suggest that TaMADS1 could be a putative SEP-like gene, and has diverse roles in flower development (Xiang et al., 2006).

WSEP gene was expressed in the inner three whorls (lodicules, stamens, and pistils) at the floral organ differentiation stage. After floral organ identities had been determined, strong expression of WSEP was observed in the palea. The expression patterns suggest that WSEP genes are not only involved in floral organ differentiation but also in their subsequent development. Furthermore, overexpression of WSEP in transgenic Arabidopsis plants caused early flowering and terminal flower formation (Shitsukawa et al., 2007). The three wheat homoeologs of WSEP showed similar genomic structure and expression profiles. By contrast, the three homoeologs of WLHS1 showed genetic and epigenetic alterations. The A genome WLHS1 homoeolog (WLHS1-A) had a structural alteration that contained a large novel sequence in place of the $\mathrm{K}$ domain sequence. The WLHS1-A protein, which lacks a K domain sequence has lost the normal MADS box function. The B and D genome homoeologs, WLHS1-B and $W L H S 1-D$, respectively, had an intact MADS box gene structure, but WLHS1-B was predominantly silenced by cytosinemethylation. Consequently, of the three WLHS1 homoeologs, only WLHS1-D functions in hexaploid wheat (Shitsukawa et al., 2007).

The expression patterns of TaSEP-1 and TaSEP-5 were similar, their transcripts were detected at low level in vegetative tissues such as coleoptile, leaf and stem, at moderate level in developing caryopses and at very high level in spikes at heading time. TaSEP-2 and TaSEP-6 showed similar expression levels in vegetative tissues and spikes. The expression of TaSEP-3 and TaSEP-4 was very similar to that of their respective rice orthologous OsMADS7 and OsMADS8 (Pelucchi et al., 2002); their transcription was restricted to spikes and developing caryopses (Paolacci et al., 2007).

The functions of other $S E P$-like genes in wheat are not fully established, partly because of the functional redundancy of these genes. For example, a loss-of-function mutant of WLHS1-A does not show any obvious phenotype (Shitsukawa et al., 2007). It has been suggested, however, that the functions of SEP-like genes in wheat may have diversified to some degree. That is, the expression patterns of $S E P$-like genes in the wheat flower are variable and the interactions of $S E P$-like proteins with the products of ABCD MADS-box genes are not identical. Establishing the functional diversification of $S E P$-like genes in wheat and deducing the roles of these genes in the morphological divergence of the floret, spikelet, and inflorescence would throw light on the evolution of the grass family.

\section{Future prospects}

Although several functional studies have identified the development role of some MADS-box genes in wheat, much remains to be studied, as compared to other species such as Arabidopsis and rice. This probably owing to the common wheat is a hexaploid species with the genome constitution AABBDD, it is difficultly to use loss-of-function analysis. Analysis of the interactions of MADS-domain proteins with other types of protein including different MADS-domain proteins will help to elucidate the molecular roles of MADS-box genes in wheat. 
Isolation and characterization the three pistils (TP) gene in wheat is also an interesting issue. Because the TP mutation posses normal spike morphology but three pistils in a floret, two more than normal plants, which made it have the potentiality to increase the grain number per spike (peng et al., 2003; 2004; 2008). According to the $\mathrm{ABCDE}$ model, the pistil is specified by class $\mathrm{C}$ and $\mathrm{E}$ gene, so it can be easy speculated that the TP gene might be a class $\mathrm{C}$ or $\mathrm{E}$ gene, but the detail need further research.

\section{References}

Alvarez-Buylla, E. R., Liljegren, S. J., Pelaz, S., Gold, S. E., Burge, V. C., Ditta, G. S., Fergara-Silva, V., \& Yanofsky, M. F. (2000). MADS-box gene evolution beyond Xowers: expression in pollen, endosperm, guard cells, roots and trichomes. The Plant Journal, 24, $457-466$

Ambrose, B. A., Lerner, D. R., Ciceri, P., Padilla, C. M., Yanofsky, M. F., \& Schmidt, R. J. (2000). Molecular and genetic analyses of the Silky1 gene reveal conservation in floral organ specification between eudicots and monocots. Molecular Cell, 5, 569-579

Angenent, G. C., \& Colombo, L. (1996). Molecular control of ovule development. Trends in Plant Science, 1, 228-232.

Chung, Y. Y., Kim, S. R., Kang, H. G., Noh, Y. S., Park, M. C., Finkel, D., \& An, G. (1995). Characterization of two rice MADS box genes homologous to GLOBOSA. The Plant Journal, 109, 45-56

Coen, E.S., \& Meyerowitz, E. M. (1991). The war of the whorls: genetic interactions controlling flower development. Nature, 353, 31-37

Coffman, F. A. (1924). Supernumerary spikelets in Mindum wheat. Journal of Heredity, 15, 187-192

Colombo, L., Franken, J., Koetje, E., van Went, J., Dons, H. J. M., Angenent, G. C., \& van Tunen, A. J. (1995). The petunia MADS box gene FBP11 determines ovule identity. Plant Cell, 7, 1859-1868.

Danyluk, J., Kane, N. A., Breton, G., Limin, A. E., Fowler, D. B., \& Sarhan, F. (2003). TaVRT-1, a Putative Transcription Factor Associated with Vegetative to Reproductive Transition in Cereals. Plant Physiology, 132, 1849-1860.

Davies, B., \& Schwarz-Sommer, Z. (1994). Control of floral organ identity by homeotic MADS-box transcription factors. In Nover L (ed), Plant promoters and transcription factors. New York: Springer, Berlin Heidelberg. pp. 235-258

Ditta, G., Pinyopich, A., Robles, P., Pelaz, S., \& Yanofsky, M. F. (2004). The SEP4 gene of Arabidopsis thaliana functions in floral organ and meristem identity. Current Biology, 14, 1935-1940

Dubcovsky, J., Lijavetzkyu, D., Appendino, L. \& Tranquilli, G. (1998). Comparative RFLP mapping of Triticum monococcum genes controlling vernalization requirement. Theoretical and Applied Genetics, 97, 968-975

Favaro, R., Pinyopich, A., Battaglia, R., Kooiker, M., Borghi, L., Ditta, G., Yanofsky, M. F., Kater, M. M., \& Colombo, L. (2003). MADS-box protein complexes control carpel and ovule development in Arabidopsis. Plant Cell, 15, 2603-2611

Feldman, M. (2001). Origin of cultivated wheat. In: Bonjean AP, Angus WJ (eds), The world wheat book $A$ history of wheat breeding. Paris: Lavoisier. pp. 3-56

Ferrandiz, C., Gu, Q., Martienssen, R., \& Yanofsky, M. F. (2000). Redundant regulation of meristem identity and plant architecture by FRUITFULL, APETALA1 and CAULIFLOWER. Development, 127, 725-734

Frederic, J. R., \& Bauer, P. J. (2000). Physiological and numerical components of wheat yield. In: E. H. Satorre, \& G. A. Slafer (eds), Wheat Ecology and Physiology of Yield Determination. New York: Food Products Press. pp. $45-65$

Fu, D., Szucs, P., Yan, L, Helguera, M., Skinner, J. S., von Zitzewitz, J., Hayes, P. M., \& Dubcovsky, J. (2005).

Large deletion within the first intron VRN-1 are associated with spring growth habit in barley and wheat. Mol Genet Genom, 273, 54-65

Goto, K., \& Meyerowitz, E. M. (1994). Function and regulation of the Arabidopsis floral homeotic gene PISTILLATA. Genes \& Development, 8, 1548-1560

Günter, T. (2001). Development of floral organ identity: Stories from the MADS house. Current Opinion in Plant Biology, 4, 75-85

Hama, E., Takumi, S., Ogihara, Y., \& Murai, K. (2004). Pistillody is caused by alterations to the class-B MADS-box gene expression pattern in alloplasmic wheats. Planta, 218, 712-720 
Hirabayashi, C., \& Murai, K. (2009). Class C MADS-box gene AGAMOUS was duplicated in the wheat genome. Wheat Information Service, 107, 13-16

Honma, T. \& Goto, K. (2001). Complexes of MADS-box proteins are sufficient to convert leaves into floral organs. Nature, 409, 525-529

Jack, T., Brockman, L. L., \& Meyerowitz, E. M. (1992). The homeotic gene APETALA3 of Arabidopsis thaliana encodes a MADS box and is expressed in petals and stamens. Cell, 68, 683-697

Jeon, J., Lee, S., Jung, K. H., Yang, W. S., Yi, G. H., Oh, B. G., \& An, G. (2000). Production of transgenic rice plants showing reduced heading date and plant height by ectopic expression of rice MADS-box genes. Molecular Breeding, 6, 581-592

Kane, N. A., Agharbaoui, Z., Diallo, A. O., Adam, H., Tominaga, Y., Ouellet, F., \& Sarhan, F. (2007). TaVRT2 represses transcription of the wheat vernalization gene TaVRN1. The Plant Journal, 51, 670-680

Kang, H. G., Jeon, J. S., Lee, S., \& An, G. (1998). Identification of class B and class C floral organ identity genes from rice plants. Plant Molelcular Biology, 38, 1021-1029

Kang, H. G., Noh, Y. S., Chung, Y. Y., Costa, M. A., An, K., \& An, G. (1995). Phenotypic alterations of petal and sepal by ectopic expression of a rice MADS box gene in tobacco. Plant Molecular Biology, 29, 1-10

Kater, M. M., Dreni, L., \& Colombo, L. (2006). Functional conservation of MADS-box factors controlling floral organ identity in rice and Arabidopsis. Journal of Experimental Botany, 57, 3433-3444

Kempin, S. A., Savidge, B., \& Yanofsky, M.F. (1995). Molecular basis of the cauliflower phenotype in Arabidopsis. Science, 267, 522-525

Kyozuka, J., Kobayashi, T., Morita, M., \& Shimamoto, K. (2000). Spatially and temporally regulated expression of rice MADS box genes with similarity to Arabidopsis class A, B and C genes. Plant Cell Physiology, 41, 710-718

Lim, J., Moon, Y. H., An, G., \& Jang, S. K. (2000). Two rice MADS domain proteins interact with OsMADS1. Plant Molecular Biology, 44, 513-527

Ma, H. (1994). The unfolding drama of flower development: recent results from genetic and molecular analyses. Genes \& Development, 8, 745-756

Malcomber, S. T., \& Kellogg, E. A. (2005). SEPALLATA gene diversification: brave new whorls. Trends in Plant Science, 10, 427-435

Mandel, M. A., Gustafson-Brown, C., Savidge, B., \& Yanofsky, M. F. (1992). Molecular characterization of the Arabidopsis floral homeotic gene APETALA1. Nature, 360, 273-277

Meguro, A., Takumi, S., Ogihara, Y., \& Murai, K. (2003). WAG, a wheat AGAMOUS homolog, is associated with development of pistil-like stamens in alloplasmic wheats. Sex Plant Reprod, 15, 221-230

Moon, Y. H., Kang, H. G., Jung, J. Y., Jeon, J. S., Sung, S. K., \& An, G. (1999). Determination of the motif responsible or interaction between the rice APETALA1/AGAMOUS-LIKE9 family proteins using a yeast two-hybrid system. Plant Physiology, 120, 1193-1204

Murai, K., Miyamae, M., Kato, H., Takumi, S., \& Ogihara, Y. (2003). WAP1, a wheat APETALA1 homolog, plays a central role in the phase transition from vegetative to reproductive growth. Plant Cell Physiology, 44, $1255-1265$

Murai, K., Murai, R., Takumi, S., \& Ogihara, Y. (1998). Cloning and characterization of cDNAs corresponding to the wheat MADS box genes. In: Slinkard AE (ed), Proceedings of the $9^{\text {th }}$ International Wheat Genetic Symposium, 1, 89-94

Murai, K., Takumi, S., Koga, H., \& Ogihara, Y. (2002). Pistillody, homeotic transformation of stamens into pistil-like structures, caused by nuclear-cytoplasm interaction in wheat. The Plant Journal, 29, 169-182

Paolacci, A. R., Tanzarella, O. A., Porceddu, E., Varotto, S., \& Ciaffi, M. (2007). Molecular and phylogenetic analysis of MADS-box genes of MIKC type and chromosome location of SEP-like genes in wheat (Triticum aestivum L.). Mol Genet Genomics, 278, 689-708

Pelaz, S., Ditta, G. S., Baumann, E., Wisman, E., \& Yanofsky, M. F. (2000). B and C floral organ identity functions require SEPALLATA MADS-box genes. Nature, 405, 200-203

Pelaz, S., Tapia-Lopez, R., Alvarez-Buylla, E. R., \& Yanofsky, M. F. (2001). Conversion of leaves into petals in 
Arabidopsis. Current Biology, 11, 182-184

Pelucchi, N., Fornara, F., Favalli, C., Masiero, S., Lago, C., Pè, M. E., Colombo, L., \& Kater, M. M. (2002). Comparative analysis of rice MADS-box genes expressed during Xower development. Sex Plant Reprod,15, $113-122$

Peng, Z. S., Martinek, P., \& Kosuge, K. (2008). Genetic mapping of a mutant gene producing three pistils per floret in common wheat. Journal of Applied Genetics, 49, 135-139

Peng, Z. S., Yang, J., \& Wei, S. H. (2004). Characterization of common wheat (Triticum aestivum L.) mutation line producing three pistils in a floret. Hereditas, 141, 15-18

Peng, Z. S. (2003). A new mutation in wheat producing three pistils in a floret. J. Agronomy \& Crop Science, 189, 270-272

Pinyopich, A., Ditta, G. S., Savidge, B., Liljegren, S. J., Baumann, E., Wisman, E., \& Yanofsky, M. F. (2003). Assesing the redundancy of MADS-box genes during carpel and ovule development. Nature, 424, 85-88

Riechmann, J. L., \& Meyerowitz, E. M. (1997). MADS domain proteins in plant development. Biology Chemistry, 378, 1079-1101

Shitsukawa, N., Tahira, C., Kassai, K. I., Hirabayashi, C., Shimizu, T., Takumi, S., Mochida, K., Kawaura, K., Ogihara, K., \& Murai, K. (2007). Genetic and Epigenetic Alteration among Three Homoeologous Genes of a Class E MADS Box Gene in Hexaploid Wheat. The Plant Cell, 19, 1723-1737

Shore, P., \& Sharrocks, A. D. (1995). The MADS-box family of transcription factors. European Journal of Biochemistry, 229, 1-13

Sommer, H., Beltran, J. P., Huijser, P., Pape, H., Lonnig, W. E., Saedler, H., \& Schwarz-Sommer, Z. (1990). Deficiens, a homeotic gene involved in the control of flower morphogenesis in Antirrhinum majus: the protein shows homology to transcription factors. EMBO J, 9, 605-613

Theissen, G., \& Saedler, H. (1999). The golden decade of molecular floral development (1990-1999): a cheerful obituary. Dev Genet, 25, 181-193

Theissen, G., Strater, T., Fischer, A., \& Saedler, H. (1995). Structural characterization, chromosomal localization and phylogenetic evaluation of two pairs of AGAMOUS-like MADS-box genes from maize. Gene, 156, 155-166

Theissen G. (2001). Development of floral organ identity: stories from the MADS house. Current Opinion in Plant Biology, 4, 75-85

Tranquilli, G., \& Dubcovsky, J. (2000). Epistatic interaction between vernalization genes Vrn- ${ }^{\mathrm{m}} 1$ and Vrn- $\mathrm{A}^{\mathrm{m}} 2$ in diploid wheat. Heredity, 91, 304-306

Tröbner, W., Ramirez, L., Motte, P., Hue, I., Huijser, P., Lonnig, W. E., Saedler, H., Sommer, H., \& Schwarz-Sommer, Z. (1992). GLOB-OSA: a homeotic gene which interacts with DEFICIENS in the control of Antirrhinum floral organogenesis. EMBO Journal, 11, 4693-4704

Weigel, D., \& Meyerowitz, E. M. (1994). The ABCs of floral homeotic genes. Cell, 78, 203-209

West, A. G., Causier, B. E., Davies, B., \& Sharrocks, A. D. (1998). DNA binding and dimerisation determinants of Antirrhinum majus MADS-box transcription factors. Nucleic Acids Research, 26, 5277-5287

Yamada, K., Saraike, T., Shitsukawa, N., Hirabayashi, C., Takumi, S., \& Murai, K. (2009). Plant Molecular Biology, 71, 1-14

Yamaguchi, T., \& Hirano, H. Y. (2006). Function and diversification of MADS-box genes in rice. The Scientific World Journal, 6, 1923-1932.

Yan, L., Loukoianov, A., Tranquilli, G., Helguera, M., Fahima, T., \& Dubcovsky, J. (2003). Positional cloning of wheat vernalization gene VRN1. Proc Natl Acad Sci USA, 100, 6263-6268

Zhou, L. L., Song, G. Q., Li, H. Y., Hu, Y. G., \& He, B. R. (2008). A MADS-Box Transcription Factor Related to Fertility Conversion in Male Sterile Wheat Lines. Acta Agronomica Sinica, 34, 598-604

Xiang, Y. Z., Zhi, J. C., \& Xian, S. Z. (2006). Overexpression of TaMADS1, a SEPALLATA-like gene in wheat, causes early flowering and the abnormal development of floral organs in Arabidopsis. Planta, 223, 698-707 


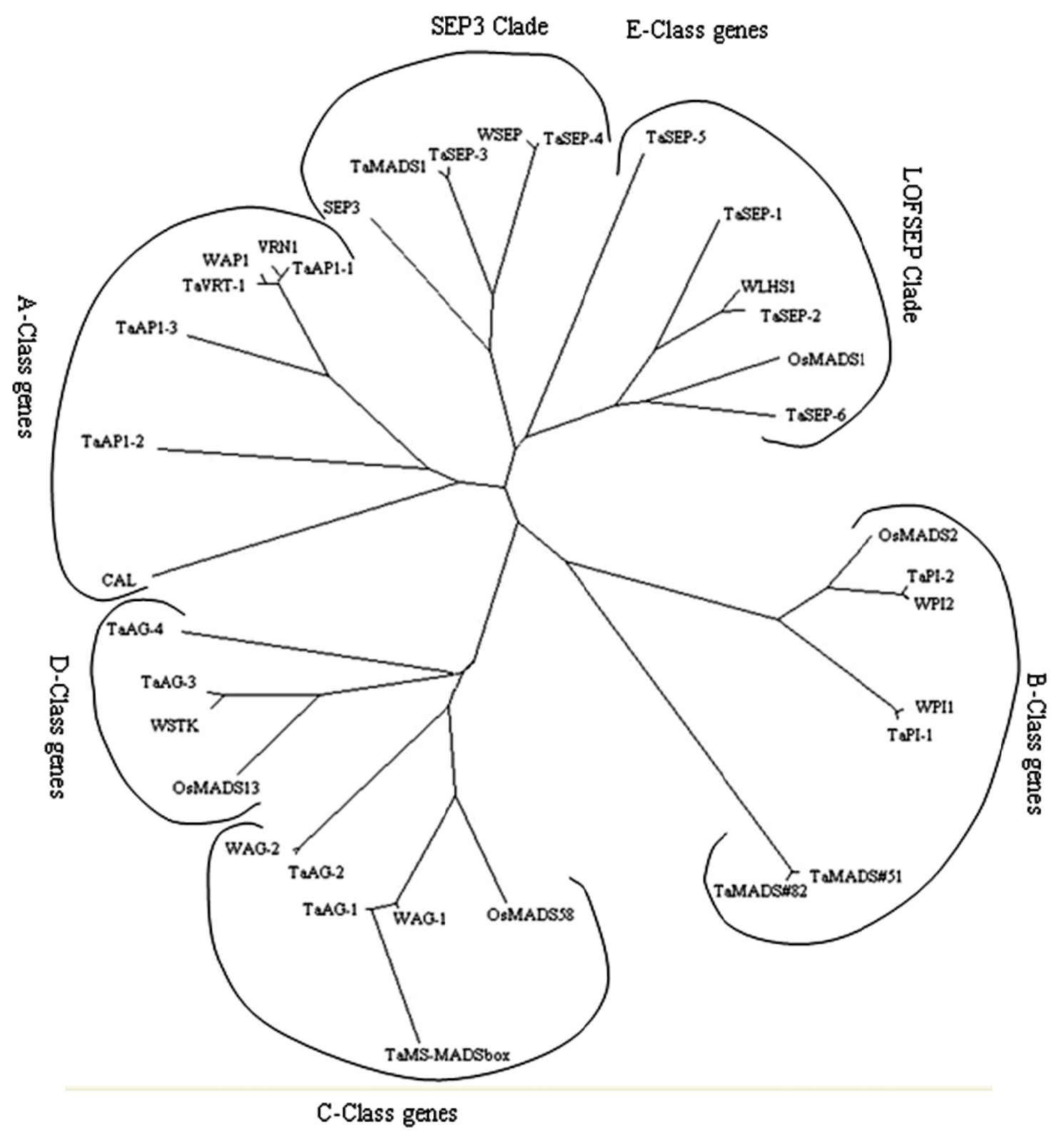

Figure 1. Phylogeny of the major classes of A B C D E genes from wheat, rice and Arabidopsis.

The phylogenetic tree was constructed using the neighbor-joining method provided by the program of clustalx. 